\title{
Mitos de la creatividad, el genio y la locura a través de la obra de Woody Allen
}

\section{Myths of creativity, genius and madness through the work of Woody Allen}

Raquel Caerols Mateo. Universidad Antonio de Nebrija

Recibido: 10-IV-2014 - Aceptado: 4-XI-2014

Resumen:

La creatividad, la creación y sus procesos han generado numerosos mitos, conformando parte del tejido del pensamiento simbólico occidental. La obra del director de cine neoyorquino Woody Allen, tantos sus películas como sus numerosos textos, armonizan un conjunto realmente exponencial de dichos mitos como referente de nuestro ser contemporáneo. Un análisis pormenorizado de los mismos, en un diálogo con los textos y teóricos principales de la creatividad, nos servirá para realizar una revisión de todo el ideario en torno a la creación artística y el Arte, como referentes centrales y constitutivos del pensamiento occidental, así como la validez de los mismos en nuestra contemporaneidad, lo que tocará a la definición misma de la creación artística, del Arte.

Palabras clave:

Arte, cine, creatividad, genio, mitos.

Abstract:

Creativity, creation and processes have generated many myths, ranking as the central constituent of the tissue that forms the western thought. The work of New York filmmaker Woody Allen, as many films as numerous texts, make up a truly exponential set of such myths as a benchmark of our contemporary being. A detailed analysis of them, in a dialogue with the main theoretical texts and creativity, will help us to make a review of all the ideas that has been created around artistic creation and Art, as constituting the central referents Western thought and the validity in our present, which will perform the same definition of artistic creation, Art.

Keywords:

Art, cinema, creativity, genius, myths. 


\section{Introducción}

Acercarse a la obra de Woody Allen, al estudio de la misma, conlleva una dificultad añadida, aquella que tiene que ver con la inmensa cantidad de estudios e investigaciones publicados de su obra. Pero si además añadimos que la labor de todo investigador es asumir el reto de un ir más allá, la coyuntura adquiere mayor complejidad, pues como dice David Lynch: "Las ideas son como peces. Si quieres pescar pececitos, puedes permanecer en aguas poco profundas. Pero si quieres pescar un gran pez dorado, tienes que adentrarte en aguas más profundas” (Lynch, 2011: 11).

Si nos adentráramos además en abordar un trabajo de Allen desde las variables más comunes y ortodoxas de la investigación científica en el campo de la cinematografía, a saber, análisis fílmico y crítica cinematográfica en torno al autor-cineasta, comparativas con otros cineastas o movimientos cinematográficos, la situación se complicaría más en los límites investigadores descritos.

No obstante, nosotros, como obligación y motivación del ámbito investigador nos proponemos bucear las aguas profundas hacia la búsqueda de ese pez. Y, desde esa conciencia e intención, aún en ese contexto ortodoxo de investigación descrito podríamos ir más allá. Pero sabemos que el cine, como pieza de Arte, es mucho más que eso. El cine, como el Arte, y los artistas, son testigos de su tiempo, son el ser de su tiempo, situando al cine en un hecho potencialmente expuesto a estudios multidisciplinares, interdisciplinares y transdisciplinares. Y hacia allí nos vamos a dirigir nosotros.

En este sentido, nuestro estudio atenderá al abordaje y análisis de los mitos del genio y la locura a través de la obra de Woody Allen, pues entendemos que su obra se presenta como objeto idóneo de estudio para este propósito. Explicamos ahora por qué.

La descripción y cualificación de este contexto, apunta al porqué, al para qué, al sentido y ser del Arte, del cine, en el pensamiento humano, en el pensamiento occidental, desde ese enfoque transdisciplinar. Este es el propósito del que partimos, separándonos de la ortodoxia del análisis y estudio del hecho cinematográfico, como hemos señalado, y en ese mismo contexto, intentar un ir más allá como ejercicio central de la profesión investigadora.

La mirada transubjetiva es el espacio del pensamiento simbólico, el espacio del arte. Mediante símbolos el artista y la sociedad, la sociedad y el artista crean sus espejos, experimentan su catarsis. Como muy bien sabemos, el concepto de catarsis no es algo nuevo, nació en Grecia, es el origen del teatro griego, pero también es el origen del sentido y el ser del Arte en el mundo occidental.

Catarsis, símbolo y espejo, símbolo, espejo, catarsis, proceso de retroalimentación entre artista y sociedad, entre sociedad y artista. Proceso de ensimismamiento como proceso central de la creación artística, catarsis, símbolo y espejo y, ahí está, Woody Allen, cineasta que conforma exponencialmente el esquema descrito. Es decir, si hay algo que no podemos negar es que Allen crea desde el ensimismamiento, y con ello no queremos apuntar al tópico de sus citadas neurosis o la de sus

34 | n 20, pp. 33-64 | doxa.comunicación 
personajes, o las dos cosas, pues muchos estudios afirman que son la misma cosa. Simplemente, afirmamos que él crea desde ese ensimismamiento y que, a su vez, ese es el ser y centro de todo proceso creador, sin él, sin esa profunda concentración que conlleva, no llegaríamos a ese gran pez dorado. Es pues, que por ello, ese proceso de ensimismamiento, linda siempre con los límites de la neurosis, no destacada ni como tópico del creador ni como tópico de la figura creadora de Allen y sus personajes, sino como variable que siempre ronda, inevitablemente, en el proceso creador.

El ensimismamiento, la catarsis, la generación de símbolos y espejos conduce a un proceso de autoconciencia, proceso de retroalimentación entre artista y sociedad apuntado anteriormente, sentido y porqué del arte, pues si hay una función del artista en una sociedad es la de generar sentido, cómo porqué y sentido de su trabajo creador.

Es porque afirmamos, una vez más, que Allen condensa esas variables y es ejemplo definidor de ese contexto teórico descrito. Pero si además, nuestras inquietudes están en investigar y entender el proceso creador y, más concretamente, hacer una indagación en las cuestiones específicas de los mitos del genio y la locura-como señalamos anteriormente-, hacerlo a través de la obra de Allen, supone conjugar una suerte de causalidades que construyen una pieza de mecano que encaja perfectamente en nuestras intenciones y objetivos.

No cabe duda de que la sociedad norteamericana a la que pertenece Allen, nuestra sociedad contemporánea por prolongación de la norteamericana como reflejo del mundo occidental, se caracteriza por ser una sociedad individualista, donde el éxito es objeto de culto, las soledades, los miedos a las enfermedades, y las neurosis y las medicaciones y libros de autoayuda proliferan por doquier para paliar los efectos de aquello. Y ahí está el hecho de que Allen, como catarsis de ese proceso desmitifica esos mitos del genio y la locura a través de su obra.

Entendemos, por tanto, que la obra de Woody Allen, se presenta como el paradigma idóneo donde los conceptos de mito y genio se han dado siempre la mano, tanto en su obra como en los mitos del "genio creador" que siempre le han rodeado. Por tanto, ahora sí podemos afirmar que en los límites de este contexto investigador es donde queremos centrar nuestro estudio en relación a la obra de Woody Allen, pues es perfecto reflejo de las variables descritas.

Por último, nos interesa especialmente el hecho de que sea un creador contemporáneo, pue es un autor que pertenece a la civilización y a la cultura que nosotros pertenecemos, y en este sentido, creemos que es una posición ideal para el estudio que nos proponemos como tarea, pues añadidos las variables socioculturales, en ese binomio artista-sociedad antes señalado.

Arte, creatividad, sus mitos, genio y locura, personalidad creadora a través de la obra de Allen, variables a través de las que entender el proceso creativo. Todo esto nos puede enseñar y/o decir el cine. 


\section{Marco teórico}

Cuando nos acercamos al tema de los genios y sus mitos observamos que todos esos mitos y creencias que han perdurado a lo largo de la historia, forman parte de la cultura y de nuestro imaginario de una forma natural y asumida.

Es por ello, por lo que comenzamos a preguntarnos por qué pensamos en los genios como esos seres excepcionales con capacidades innatas, como tocados por una "mano divina”; o en seres rodeados de familiares músicos, pintores, que antes de empezar a caminar les pusieron un violín entre sus manos; o por qué pensamos en ellos como seres aislados, en cierto modo, de la sociedad, raros, excéntricos, melancólicos o incluso locos.

Las respuestas pueden ser múltiples y variadas. Pensamos, también, que todas las sociedades o culturas necesitan personas de referencia, seres con ese halo de "divinidad" a los que admirar (símbolos, en definitiva). A la par que en esta contemporaneidad, a muchos creadores les haya interesado todas estas consideraciones en torno a ellos.

Las biografías sobre genios también han contribuido a consolidar estas ideas. Los biógrafos han encontrado un material ideal para fabular, novelar y, en definitiva, crear un género literario propio.

El tema de la locura también ha servido para crear ese misterio e inquietud en torno a la figura del genio. Por otro lado, no hay que olvidar que muchas creaciones de las personalidades más destacadas de la historia -por sus contribuciones al pensamiento humano-, han sido contrarias a lo establecido o, de alguna manera, han desestabilizado las bases del poder. Es posible que este hecho, haya motivado esa etiqueta negativa de seres enfermizos o locos.

Todas estas reflexiones nos llevaron a cuestionarnos dichos mitos y a pensar qué había de cierto en ellos y, consecuentemente, qué nos dice el Arte, sus mitos y sus símbolos. La historia nos ha dejado combinaciones de lo más inverosímiles e imprevisibles sobre los hilos que tejieron la historia y la consecución de acontecimientos que conformaron las grandes teorías y los personajes más relevantes del pensamiento humano. Así, alguna de esos talentos más transcendentales para nuestra historia han tenido entornos privilegiados para desarrollar sus capacidades, como Mozart; o, en el lado opuesto, Matisse, que comenzó trabajando como pasante en un gabinete jurídico, y de forma inesperada, a una edad tardía, se dedicó por completo a la pintura; o el caso de Shakespeare, que no disfrutó de una gran educación, y escribió las más grandes obras de la dramaturgia; sin olvidar a Van Gogh, que los momentos más estables de su enfermedad los encontró en la soledad y la dedicación exclusiva a la pintura; para otros, su propio trabajo creativo pudo ser causa de obsesiones y enfermedades.

Por todo ello, nos planteamos que la historia ha mostrado que el abanico de personalidades geniales y creativas es tan amplio y variado como genios han existido. En este sentido, es interesante la reflexión que se encuentra en el libro Creatividad. El genio y otros mitos: 
"Así pues, el individuo se hace artista tratando de atender a ciertas necesidades internas y, presumiblemente, la obra que produce sirve al propósito de satisfacer dichas necesidades. Como seguramente hay tantos conjuntos específicos de necesidades y de formas de satisfacerlas como personas, cada artista desarrolla su estilo propio e individual, en el cual pesan su personalidad y sus experiencias" (Weisberg, 1988: 116).

El conjunto de reflexiones y análisis que exponemos a modo de contexto teórico, nos llevan al principio de nuestros intereses investigadores, a saber, ¿qué es la creatividad?, ¿de dónde vienen las ideas?, si hay en sí unos rasgos específicos que definan una personalidad creadora, o qué entendemos por genio. Para dicho abordaje de la cuestión, vamos a pivotar entre las variables socioculturales y las centradas en el sentido y el porqué de la creación artística para el individuo, en cuyo contexto el tema de los mitos también es fundamental objeto de análisis. Así, partimos de la hipótesis que se asienta sobre el hecho de que todo nuestro ideario sobre la creatividad, la creación artística y los genios son fruto de los mitos nacidos a la luz de un contexto histórico. Son construcciones de una sociedad a través de los cuales aspira a entenderse y explicarse. Mitos que representan símbolos, símbolos sobre el que se construye el ideario de una civilización, pero que a la vez son la parte central del pensamiento y el proceso creativo, como explicación intrínseca del ser humano, con explicación intrínseca del porqué y el sentido del Arte para el hombre. El pensamiento transubjetivo, el pensamiento simbólico como patrimonio del ser del Arte, como motor de supervivencia y evolución de la especie, el Arte en su capacidad y necesidad de generar sentido.

A modo de apunte, traemos aquí un fragmento de una biografía del pintor Modigliani -pero que podríamos encontrar en la biografía de cualquier otro artista-, para mostrar con él la significación del mito a la que acabamos de aludir:

“Quizá se deba al nombre. "Amadeo Modigliani” tiene resonancias. Su resonancia inspira ecos de melancolía elegíaca, lograda invención de un personaje novelesco lleno de poesía trágica; quizá sea precisamente esta razón por la que desde siempre Modigliani ha dado alas a la fantasía y a la literatura sin apenas estimular una descripción objetiva y serena de su vida y obra... Probablemente no haya otro pintor de la modernidad clásica tan cargado de leyendas, mitos y clichés como Amadeo Modigliani: sobre él se han escrito novelas y obras de teatro, se han rodado películas que idealizan desmesuradamente su vida de bohemio; incluso las obras de historia del arte rebosan de anécdotas glorificadoras. Al mismo tiempo, se dispone de una muy reducida cantidad de documentos verídicos sobre la vida del pintor, por lo que no es tarea sencilla reconocer al auténtico Modigliani detrás de todos estos rasgos novelescos" (Krystof, 2000: 7).

Y en el contexto de estas problemáticas ipor qué Woody Allen? En primera instancia, nos planteamos que debíamos buscar en una obra o creador que conociéramos en profundidad y que, además, como motor de todo trabajo investigador, nos motivara especialmente, y en este caso, no podía ser otro que Woody Allen.

La circunstancia de conocer la obra de Allen nos llevaba, consecuentemente, a conocer sus temáticas principales: la religión, la muerte, el sexo, pero también el psicoanálisis, la crítica a los intelectuales, y con ello, la idea del genio, el talento, 
etc. Es pues, que no resultó casual que pusiéramos nuestra atención en su obra para llevar a cabo un estudio sobre la idea de genio, locura, creatividad y sus mitos en la cultura occidental.

Y así, nos pusimos a indagar pormenorizadamente sus obras más significativas. Esta introspección, sacó a la luz mucho más de lo que teníamos previsto, y descubrimos que las variables y temas que eran de nuestro interés forman parte de la obra de Allen de una forma central y transversal. Y que el peso del contexto de estas temáticas y de su base conceptual respondía a toda una tradición teórica en el campo de la creatividad.

Conjugar sus planteamientos teóricos, tan bien construidos en sus guiones y en los diálogos de sus personajes tan perfectamente definidos y perfilados, nos permitía una intensa revisión de los principales conceptos de la creatividad y sus mitos en el pensamiento occidental. Los conceptos asentados sobre los mitos de la creatividad, el genio y la locura que quedan recogidos en sus películas, no son casualidad, gratuitos, sino que son un espejo en el que mirarnos, respondiendo al paradigma occidental de la creación artística. O dicho de otro modo, entender la creación artística, sus parámetros, sus procesos, sus mitos es entender el conocimiento sobre el que está construido nuestro pensamiento.

Intentaremos mostrar que todas estas cuestiones que encontramos en sus películas, están recogidas en forma de constructos teóricos en los textos de referencia sobre la creatividad y sus mitos, son fruto de un largo recorrido que ha conformado el pensamiento occidental contemporáneo. Con ello, intentaremos entender la significación del Arte, la creatividad, la genialidad, el talento y sus mitos en el pensamiento y la cultura occidental. Que supondrá, además, entendernos y entender nuestro pensamiento creativo, entender nuestra forma de pensar y/o crear, a través de la obra de Allen, a través de los mecanismos con los que desarrolla su trabajo y su proceso creativo, configurándose así como una figura exponencial de las cuestiones expuestas. Todo ello nos lega el cine, todo ello nos lega el Arte.

\section{Metodología}

La metodología se ha basado en una revisión de la filmografía de Woody Allen y de sus textos más relevantes, a la par que una exploración de los textos y estudios de mayor impacto sobre la creatividad y sus mitos. Siendo así que dichos estudios nos han servido, por un lado, de material para el análisis de la obra de Allen desde una perspectiva diferente a la habitual en la teoría cinematográfica, poniendo de relieve la transversalidad del cine, del Arte; y por otro, para construir un mapa de las principales tesis de la creatividad y sus mitos en el pensamiento occidental -partiendo de la articulación de un diálogo entre ambos materiales-. Woody Allen, el cine, el Arte, como un espejo a través del cual mirarnos. Eso es también para Woody Allen el cine, la creación artística.

Las películas seleccionadas y los diálogos escogidos tienen la intención de establecer una serie de hipótesis en relación a las principales ideas, a todo su imaginario referente a las leyendas y fábulas sobre los genios que han vertebrado su obra; así como a la de conformar un conjunto de variables de las principales teorías sobre la creatividad, los genios y sus mitos.

38 | n 20, pp. 33-64 | doxa.comunicación 
Con el conjunto de diálogos seleccionados de las diferentes películas se tratará de construir un hilo conductor, a modo de guión de cine, de argumento de guión cinematográfico, encaminado a conformar dicho conjunto teórico. Por tanto, el método se basa en una dialéctica y en el método inductivo, es decir, de las propuestas particulares de Allen y de los textos y estudios sobre creatividad hasta el intento de establecimiento de generalidades a modo de conjunto teórico en las conclusiones.

El guión referido se ha elaborado a partir de la selección de las siguientes películas y los diálogos de las mismas:

a. Material audiovisual seleccionado

i. La infancia del genio:

ii. Hijo... todavía puedes llegar a ser alguien (Días de radio, 1987).

iii. La infancia en Brooklyn (Annie Hall, 1977).

iv. Las primeras visitas el psiquiatra (Annie Hall, 1977).

v. Hay niños genios felices... (Días de radio, 1987).

b. Los genios:

i. $\quad$ Algunas reflexiones...: Sócrates, Nietzsche, Freud (Hannah y sus hermanas, 1986).

ii. Mi admirado genio me ha fallado (Delitos y faltas, 1989).

iii. Los "genios" y los "estúpidos" (Manhattan, 1979).

iv. El "genio" y el "matón" (Balas sobre Broadway, 1994).

c. "Los intelectuales sólo matan a los suyos" W. Allen:

i. El cerebro... el órgano más sobrevalorado (Manhattan, 1979).

ii. Usted no sabe nada sobre Marshall MacLuhan (Annie Hall, 1977).

d. ¡Estos psicoanalistas modernos!:

i. Tu autoestima está casi por debajo de la de Kafka (Manhattan, 1979).

ii. Sólo llevo 15 años en el psicoanalista (Annie Hall, 1977).

iii. Tu psicoanalista ha hecho una perfecta introspección analítica (Annie Hall, 1977).

iv. Mi psiquiatra me sugirió que tomara Darvon (Sueños de un seductor, 1972). 
v. Era un presunto suicida (Annie Hall, 1977).

e. La locura...

i. $\quad$ Mi hermano cree que es una gallina (Annie Hall, 1977).

\section{Material textual seleccionado}

También hemos realizado una revisión de los principales textos de Allen, que apoyan y completan lo recogido en los diálogos de las películas seleccionadas, dando así evidencia de la importancia y peso de estos temas en la obra de Woody Allen. Son, pues, textos, que no aparecen físicamente como tal en el presente trabajo, -por una cuestión básica de espacio-, pero que hemos decidido referenciar para ampliar la exploración del mundo creativo de Allen y dar con ello, mayor rigor a nuestras hipótesis de trabajo.

La labor de Woody Allen como humorista en sus primeros años de carrera ha dado como fruto numerosos monólogos y escritos. A partir del libro Woody Allen en imágenes y palabras (Allen y Sunshine: 1993), hemos hecho una pequeña selección de todo ese material.

Las variables son las mismas: desmitificación en relación a la infancia de los "niños genios"; los mitos del artista y la crítica a los intelectuales; el psicoanálisis, la locura y su relación con la genialidad. Los textos son los siguientes:

a. La infancia del genio:

i. El niño sensible.

ii. Un niño precoz.

iii. Jugar a pelota.

iv. La venganza de Lovborg contra su madre.

v. Llamad a vuestra madre.

b. Los genios y los intelectuales:

i. Confiaban profundamente en la lógica.

ii. Me habría gustado ser Sócrates.

iii. Es tu gran oportunidad de morir por la verdad.

iv. Einstein le escribió en cierta ocasión. 
v. El propio Goethe.

vi. La generación perdida.

vii. Mi hermano Theo.

c. El psicoanálisis y la locura:

i. ¡Estos psicoanalistas modernos!

ii. Yo soy psicoanalista, no un mago.

iii. Le gustará la psicoterapia de grupo.

iv. Ozymandias Melancholia.

v. Su problema eran las mujeres.

Por último, a modo de apéndice, hemos seleccionado el relato "Para acabar con las biografías" del libro Como acabar de una vez por todas con la cultura (Allen: 1998), pues resulta especialmente significativo como prototipo de "biografía de un genio".

d. Apéndice:

i. Para acabar con las biografías.

\section{La creatividad y Woody Allen}

“El talento es pura suerte”, nos dice Allen en su película Hanna y sus hermanas. Esta afirmación, que nos puede parecer excesivamente básica en su conceptualización, apunta a la tradicional dialéctica del origen y los ingredientes que constituyen la creatividad y la personalidad creadora. Así como al hecho de responder a toda una tradición del sentido de la creación artística en el pensamiento occidental y los mitos del genio y la locura, apoyada en el compendio de estudios e investigaciones en torno a la creación artística y sus mitos.

Es por ello, que un tema recurrente en sus filmes sea la crítica mordaz a los intelectuales, y se acerque, con sarcasmo e ironía, a los que son considerados los grandes genios de la historia. Se puede decir que desmitifica a estos hombres y mujeres que han pasado a la historia como excepcionales. Es así, que él entiende la creatividad y la genialidad, no como algo que pertenezca a unos pocos, sino una forma de ser, de estar y de entender el mundo.

Así pues, en relación a la afirmación expuesta de Allen, podemos decir que supone un planteamiento teórico que sitúa el origen de la creatividad y de la personalidad creadora en una suerte de variables del destino, en puro destino. Este enfo- 
que arraiga esencialmente, por un lado, en nuestra tradición del pensamiento romántico, que contemplaba el origen de la creatividad en un estadio que se escapaba de toda posibilidad de ser educada, de toda posibilidad de ser adquirida en el proceso de aprendizaje: "el poder autónomo, la no-racionalidad y la definitiva imposibilidad de aprendizaje de la creatividad artística al más alto nivel" (Kemp, 2000: 271); o como afirmó uno de los máximos exponentes del romanticismo William Blake: "El conocimiento de la belleza no se adquiere, nace con nosotros" (Bentley apud Kemp, 2000: 269). Por otro lado, dichos planteamientos, apuntan a ese conjunto de textos, de tradición teórica, que sitúan el origen de la creatividad en un conjunto de variables poco cognoscibles, y que, poniendo el acento en la variable histórica, la balanza se inclina hacia los juegos del destino, poniendo sus propias reglas:

“Claramente, ni las diversas cualidades y propensiones que son el origen del "talento" y del impulso a la creatividad artística, ni el papel que el artista tiene en un sociedad cualquiera, se derivan de unas condiciones fijas, sino que, más bien, están sometidos a innumerables modificaciones que sólo podemos comprender a la luz de la situación histórica" (Kris y Kurz, 1991: 21).

Ahora bien, si la conceptualización de la creatividad, su origen y los rasgos que conforman la personalidad creadora a la que apunta Allen a lo largo de toda su obra nos llevan a hacer un estudio y una revisión de la significación de estas cuestiones en el pensamiento occidental, también nos conduce, inevitablemente, a hacer una revisión sobre el estado en el que se encuentra esta cuestión en nuestra contemporaneidad. A revisar, pues, la validez de la tradición de estas corrientes teóricas en nuestra contemporaneidad, a entender, como decimos, nuestro ser y estar, pues el cine, el arte, son conocimiento.

En ese sentido, a la luz de las investigaciones contemporáneas en el campo de la educación, la psicología, la neurociencia, ¿podemos seguir apoyando y apoyándonos en esa tradición teórica? Sabemos que esos planteamientos siguen estando presentes en la savia de nuestro pensamiento ¿̇pero tiene sentido que sigan teniendo validez? Aunque el cerebro aún sigue siendo un gran desconocido, los campos de la educación, la psicología o la neurociencia ya nos han confirmado que la creatividad, así como la intuición y el inconsciente, -como herramientas centrales de los procesos creativos- se pueden educar. Que la creatividad sea una suerte del destino está, en nuestra contemporaneidad, en tela de juicio, a la luz de las investigaciones señaladas.

Este diálogo entre la tradición y el presente, guiará todo nuestro recorrido por la obra de Allen y los textos y estudios sobre la creatividad y sus mitos, -en un diálogo permanente con aquella- . Creatividad, procesos creativos, genialidad y sus mitos, a través de la obra de Allen. 


\section{Una introspección a los diálogos y los textos seleccionados de Woody Allen}

\section{a. La infancia del genio}

Las ideas que giran en torno a la niñez y juventud del artista han variado a lo largo de la historia, pero de forma genérica se pueden agrupar en una serie de enfoques teóricos:

"Un punto de vista expresa que los acontecimientos de la infancia tienen una importancia decisiva para el futuro desarrollo del hombre, de aquí los intentos de demostrar la temprana influencia del destino en la vida de los grandes personajes de la historia. El otro interpreta estas primeras informaciones sobre la vida de los héroes no como precursoras en cuanto a causalidad, sino como signos premonitorios; ve en las experiencias del niño un indicio de sus futuros logros y las considera como prueba de la temprana consumación de singularidad" (Kris y Kurz, 1991: 31).

Kris y Kurz, hacen referencia a otros dos puntos de vista:

“... nos damos cuenta de una polaridad que tuvo gran importancia en la cultura griega en general. Se originó en la mitología y se infiltró en los escritos de la historia. Un extremo está representado por el autodidacta, y se refleja en el ascenso a héroe de la cultura del individuo creador. El otro extremo refleja la necesidad de anclar firmemente el logro individual en la sucesión dinástica, proceso que podemos llamar "genealogización” (Kris y Kurz ,1991: 35-36).

Barajando estas variables, a saber: las fuerzas del destino, las capacidades innatas expresadas desde la niñez, la importancia del autodidacta o del maestro, observamos que Woody Allen bebe de esta tradición para construir sus personajes, es con esta materia con la que teje sus personajes.

Allen hace una parodia de todos estos mitos que forman parte de la infancia del genio. Y en ese sentido, como premisa de partida, apuntamos que los contextos en los que aparecen los niños de sus películas, no se caracterizan por unas variables ideales para que desarrollen sus capacidades. Es decir, Woody Allen se enmarca dentro de la idea de las capacidades innatas, de la casualidad del talento, de que el talento es pura suerte. Su texto Jugar a la pelota es buen ejemplo de este enfoque teórico.

Por otro lado, se puede establecer una diferenciación entre el concepto de talento y el de creatividad. El talento lo entiende como una serie de capacidades para pintar, dibujar, escribir o desarrollar cualquier otra actividad que requiera una serie de capacidades determinadas. Es evidente, por tanto, que en este caso el talento y la creatividad son inherentes. Pero la creatividad, no la entiende como un concepto exclusivo de la creación artística, científica o de cualquier otra índole, sino que la creatividad es constitutiva del ser humano. Algo necesario, sin lo que el ser humano no se podría entender. Por eso, la figura del autodidacta es fundamental en toda su filmografía. Pero no lo representa como héroe, sino como una actitud (la actitud de aprendizaje, de curiosidad, de sorpresa), como la única posibilidad de comprender y enfrentarse a la vida. 
Vemos que los niños que aparecen en los diálogos seleccionados, son imaginativos, creativos o precoces. Para ellos es una necesidad, pues es su herramienta para escapar de una realidad que les es hostil. Pero no sólo los niños, también la madre de Días de radio (Allen, 1987). Su hijo le acusa de estar escuchando siempre la radio, pero para ella es su mundo, un instrumento que le ayuda a imaginar y soñar.

Cuadro 1: Hijo... todavía puedes llegar a ser alguien (Días de radio, 1987) Interior. Casa. Día

$[\ldots]$

Joe: (dirigiéndose al padre) ¿Me das 15 centavos para el anillo del vengador?

Martin: ¿Crees que soy una máquina de hacer dinero?

La madre: presta más atención a tus estudios y menos a la radio.

Joe: tú siempre estás escuchando la radio.

Madre: Es diferente, nuestras vidas ya están destrozadas, tú tienes la oportunidad de llegar a ser alguien.

\section{Fuente: Allen, W. (1987): Días de radio}

El medio educativo lo representa como un lugar de frustración, que estandariza y, en cierto modo, excluye. Así lo refleja todos esos "niños prototipo" que crea como compañeros de clase y que son fruto de un medio educativo que él lo muestra como desfavorable para la imaginación o la creatividad.

\section{Cuadro 2: La infancia en Brooklyn (Annie Hall, 1977)}

Interior. Aula. Día.

En la pizarra reza: Martes, 1 de Diciembre. Varios maestros y maestras. Un maestro escribe una ecuación en la pizarra.

Voz de Alvy: Recuerdo muy bien al profesorado de la escuela pública. ¿Saben? Teníamos una frase hecha que decía: «Los que no valen para otra cosa, se hacen maestros, y los que no valen para maestros, dan clase de gimnasia». Y, bueno, ah, claro, los que no valían para nada, me parece a mí, los mandaban a nuestra escuela.

Un maestro escribe en la pizarra «Transporte»y «Administración». Los alumnos están sentados en sus bancos, y, en la última fila, se halla Alvy niño.

Voz de Alvy: He de confesar que mis compañeros de clase siempre me parecieron unos imbéciles. Como, por ejemplo, Melvyn Greenglass, con su cara redondita, y Henrietta Farrell, siempre la Señorita Perfección en persona. Y, desde luego, Ivan Ackerman, que jamás contestaba como es debido. Jamás.

Ivan: Siete y tres son nueve.

Alvy niño se lleva la mano a la cabeza, mientras otro compañero le mira.

Alvy niño: Ya entonces me daba cuenta de que no eran más que una pandilla de memos.

En 1942, yo había descubierto también a las mujeres.

Fuente: Allen, W. (1999): Annie Hall, Barcelona: Tusquets 
Otra muestra de lo que crea este modelo educativo, según el abordaje de Allen respecto a la cuestión que nos ocupa, son las figuras del "niño sensible" frente al "niño genio" de la radio. Un genio de las matemáticas cuyo coeficiente de inteligencia es elevadísimo. Allen parodia los parámetros establecidos para medir la inteligencia y con ello crear "niños modelo". Lo innato del talento y la imposibilidad de que el ámbito educativo pueda desarrollar las capacidades no innatas y que pueda educar y desarrollar las variables de la creatividad, vuelve a estar presente.

Cuadro 3: Hay niños genios felices... (Días de radio, 1987)

Exterior. Zoo. Día

El único famoso de la radio al que conocimos fue un genio de las matemáticas de 14 años que participó en un concurso llamado "Los niños geniales" que a mi padre le encantaba.

Martin: ese es un chaval de la radio que es genial.

La madre: es verdad.

Martin: (a la madre susurrando): ese es uno de los niños genial, (al hijo), mira, mira, ese es uno de los niños geniales de la radio. (Se dirige a la otra pareja). Eh, eh, perdonen, perdonen, nosotros disfrutamos muchos escuchando a su hijo por la radio. Eres un genio.

Niño de la radio: mi coeficiente de inteligencia es de 160 y eso es extraordinario se mire como se mire.

Martin: y este es nuestro hijo (y le da una pequeña torta dirigiéndose a él), "Di hola". Joe: Hola.

El niño de la radio: encantado de conocerte (le tiende la mano). Aunque tal vez emplear la palabra encantado sea una exageración (se limpia la mano).

La madre: su hijo es un genio de las matemáticas.

Martin: Eh, rápido ¿cuántas son 1750 divididas por 13 millones? (se ríe).

La madre: va, Martin... (le da un pequeño codazo y el padre se ríe).

Martin: (dirigiéndose a su hijo, dándole un pequeño cachete) $\mathrm{Y}$ este tonto no puede aprobar un sencillo examen de aritmética.

Niño de la radio: bueno, si me disculpan (y se va).

La madre: Caray, qué chaval, qué bien hablado.

Martin: (se dirige al hijo dándole unos golpes en la cabeza): ¿Por qué no puedes ser un genio? Yo te diré por qué no puedes ser genio, porque siempre estás escuchando la radio. Ponte la gorra, anda (y se alejan).

Fuente: Allen, W. (1987): Días de radio

El niño de la película Annie Hall (Allen, 1977), que se ve extraño entre sus compañeros, también lo representa como más sensible o precoz. Pero es cierto que, por otro lado, pone en duda o ironiza sobre todos estos mitos que existen del "niño especial", del niño que a una edad temprana tiene que visitar al psiquiatra. Una muestra de ello son también los textos $E l$ niño sensible y Un niño precoz. 
Cuadro 4: Las primeras visitas el psiquiatra (Annie Hall, 1977)

Interior. Consulta del médico. Día.

Alvy niño está sentado en un sofá junto a su madre.

Madre: Tiene una depresión muy grande. De repente, ya no hay forma de que haga nada.

Médico (asiente con un cigarrillo en la mano): ¿Por qué estás deprimido, Alvy?

Madre: Cuéntaselo al Dr. Flicker. Ha sido algo que ha leído.

Médico: Algo que ha leído, ¿eh?

Alvy niño: El universo se expande.

Médico (off): ¿El universo se expande?

Alvy niño: Bueno, el universo es todo y, si continúa en expansión, acabará por estallar, ¡y eso sería el fin de todo!

La madre se vuelve hacia Alvy y grita con grandes aspavientos.

Madre: ¿Y a ti qué te importa? (Al médico.) Ya no hace los deberes.

Alvy niño: ¿Y para qué?

Madre (gesticula): ¿Qué pinta el universo en todo esto? ¡Tú vives en Brooklyn! ¡Y

Brooklyn no se expande!

Médico (off): Y no conocerá expansión sin que (gesticula) pasen antes billones de años,

Alvy. Hemos de procurar pasarlo bien mientras sigamos aquí, ¿eh? (Ríe.)

Fuente: Allen, W. (1999): Annie Hall, Barcelona: Tusquets

En los textos La venganza de Lovborg contra su madre y Llamad a vuestra madre, hace una crítica a ciertos contextos de la infancia. No ha sido para el niño el entorno ideal. La sensibilidad que desarrolla el niño del primer texto, le limita más que le posibilita. Parece que una especial sensibilidad no es la causa de sus angustias. Es un niño asustadizo, que sufre "angustias" y "humores", pero que, a la vez, su imaginación es su instrumento esencial para escapar de esa realidad. En el segundo texto, este enfoque de la cuestión vuelve a aparecer, pero en el niño ya adulto. El desarrollo de la sensibilidad de este niño nada tiene que ver con la idea mítica que tenemos al respecto.

Lo expuesto hasta aquí resulta de un diálogo entre las referencias teóricas más relevantes de la materia y los diálogos, personajes y textos de Woody Allen, mostrando, por un lado, de dónde parten los enfoques sobre la creatividad sobre los que se sustenta la obra de Allen. Por otro, este entretejido de referencias teóricas, cine y textos nos ayuda a conformar un mapa sobre el origen de la creatividad, el abordaje de la misma desde la infancia, según el mundo creativo de Allen, pero extrapolable a la conformación de una genealogía de la creatividad en el contexto concreto de la infancia, en relación al planteamiento de este epígrafe.

Así pues, sintetizamos y dibujamos el mapa de la creatividad en la infancia, sobre lo innato y adquirido, sobre las características del individuo como potencialmente creador y las variables del entorno, a saber, entorno sociocultural, educación, familia, etc. Desde el punto de vista del individuo, desde los rasgos de la personalidad, de lo que denominaríamos carác- 
ter, Allen ya pone en cuestión que exista un patrón determinado de la personalidad creadora, o que haya unos rasgos específicos. En primera instancia, parte del principio que entiende la creatividad como un rasgo identificativo del ser humano, como una cuestión primaria de supervivencia, y que por tanto, los patrones y la materialización de esos comportamientos, tiene tantas traducciones como personas. Este enfoque teórico, entronca con la tradición clásica desde la que se conformó nuestro pensamiento occidental. Dicho enfoque queda especialmente sintetizado en el siguiente fragmento:

"No tengo yo una idea muy original de la poesía. Me parece que equivale a la poyesis platónica, en la idea de creación o de construcción. Es como un líquido que toma la forma del recipiente en que se vierte. Hay poesía de pintura, de literatura, de música, de escultura, de arquitectura...Habrá incluso una actitud poética que no se materialice en nada sino en procurar estarse ante las cosas con una posición de aprendizaje, de pregunta, de perplejidad: algo que no es más que una vía de conocimiento" (Gala, 1977: 9).

Es aquí donde se encuentra la razón de la desmitificación de Allen cuando aborda estas cuestiones. ¿Pero qué sucede si nos introducimos en el análisis las variables socioculturales, las variables del entorno? Pues en principio, entiende que los elementos del entorno son determinantes, sin embargo, hace una crítica feroz al ámbito educativo. Es pues, que la circunstancia para que se dé la materialización del talento, los rasgos de la creatividad, está en que entren en juego una serie de elementos, que se salen de cualquier patrón recogido en los mitos que conforman nuestra cultura. De tal manera, que podríamos afirmar que las variables del entorno son determinantes, pero situando a la educación como un valor condicionante pero no determinante, apoyándose en las posturas que cargan el peso de la balanza en lo innato de la creatividad. Descansado, en definitiva, en la tradición romántica que afirma como credo que el conocimiento de la belleza, la creatividad, el genio, el talento, no es educable. Su postura, al respecto, es clara frente a la tradición teórica, lo innato y el desarrollo autodidacta del niño, es decir, en un proceso de superación de las circunstancias externas. Las variables del entorno son determinantes pero, en especial, las herramientas educativas para el desarrollo de la misma son, esencialmente, solo condicionantes, meros condicionantes. El análisis de los diálogos de la película Balas sobre Broadway en el capítulo El "genio" y el "matón", nos dará buena cuenta de ello.

No obstante, esa postura de Allen, como decimos, bebe, principalmente, de la tradición romántica del pensamiento occidental. Pero no solo queremos configurar un esquema del concepto de creatividad y los mitos del genio en torno a la obra de Woody Allen y, por ende, de nuestra contemporaneidad, sino que también lo queremos utilizar de excusa para dar un paso más allá en relación a las teorías asentadas sobre la creatividad. Así pues, como señalamos anteriormente, desde la disciplina y campo de conocimiento de la creatividad, estamos en disposición de superar esas teorías, como un necesario avanzar en las teorías de la creatividad, y que dicho avanzar tocará, directamente, a la propia definición del Arte. Es decir, las investigaciones más recientes desde el ámbito de la creatividad, la educación, la psicología y la neurociencia nos dicen que la intuición "es una acumulación de conocimientos, no una operación misteriosa" (Marina, 2013: 120) y que el 
inconsciente se puede educar, el "inconsciente adiestrado" lo denomina Marina: "El aprendizaje de la creatividad consiste en el adiestramiento de nuestro sistema productor de ocurrencias” (Marina, 2013: 90).

El cerebro sigue siendo un gran desconocido y en los mecanismos de la creatividad intervienen mecanismos muy complejos, pero sobre lo que hay un consenso desde las diferentes disciplinas que participan en las investigaciones sobre la creatividad es que ésta, puede y debe ser desarrollada y educada.

\section{Los genios y los intelectuales}

¿Qué nos dicen los teóricos sobre la figura del genio y sus mitos? "La alta estima expresada en las biografías helenísticas,...ponían a los artista a la altura de los príncipes...” (Kris y Kurz, 1991: 50); el poeta:

“...era un "instrumento de la deidad”, agraciado con auténtica inspiración y dotado del entusiasmo como Platón indicó en su Fedro, la idea de la posesión divina del poeta surgió de las prácticas religiosas; es el resultado de la creencia de que las predicciones y augurios de las sacerdotisas y las profetisas se llevan a cabo por "locura divina”. Al poeta y al rapsoda se les atribuye este éxtasis divino, pero se les niega al pintor o al escultor > (Kris y Kurz, 1991: 51);

en el Renacimiento esta idea cambia, pero bebe de la misma fuente:

“...surgió inevitablemente la imagen de un artista que crea su obra llevado de un impulso incontrolable, en una mezcla de "furia y locura" parecida a la intoxicación. Esta idea tiene sus raíces, como hemos intentado demostrar, en la teoría del arte de Platón, pero hasta el Renacimiento no se le atribuyó a pintores y escultores la capacidad de auténtico éxtasis>> (Kris y Kurz, 1991: 55).

A lo largo de la historia, ha estado presente el mito del genio como ser "tocado por los dioses". Como se hace evidente en los diálogos de las películas seleccionadas, Woody Allen priva de estos atributos a los grandes genios de la historia, esencialmente, hace parodia de estos mitos. Sus reflexiones sobre Sócrates, Nietzsche, Freud...son buen ejemplo de esta cuestión que tratamos de evidenciar:

Cuadro 5: Algunas reflexiones...: Sócrates, Nietzsche, Freud (Hanna y sus hermanas, 1986)

Mickey (Voz en off): He leído a Sócrates, por cierto que tenía la costumbre de cepillarse a jóvenes griegos, qué me va enseñar a mí. Y Nietzsche, con su teoría del eterno retorno. Él ha dicho que la vida que vivimos, la vamos a vivir una y otra vez de la misma forma durante la eternidad. Fantástico, creo que tendré que volver a ver Sonrisas y lágrimas, no vale la pena..Y Freud...otro pesimista. Durante años asistí a sesiones de psicoanálisis, mi pobre analista terminó hecho polvo. Al final dejó su trabajo y abrió un restaurante vegetariano (Allen, W. 1986. Hannah y sus hermanas).

Fuente: Allen, W. (2000): Hanna y sus hermanas, Barcelona: Tusquets 
En otros textos como en el titulado Es una gran oportunidad de morir por la verdad, hace una parodia de la filosofía de Sócrates. Y aparece de nuevo lo miserable, lo mediocre y, en definitiva, humaniza a esos seres que la cultura ha divinizado.

Woody Allen rechaza esta idea de "seres superiores”. Cuestiona el “saber institucionalizado", la educación como institución, por su peligro de "exclusión" frente al desarrollo de la creatividad. Un ejemplo claro es su libro Cómo acabar de una vez por todas con la cultura (Allen, 1998). En el contexto de nuestras indagaciones este título es especialmente esclarecedor para entender la visión de Woody Allen sobre los mitos culturales.

No sólo la historia ha demostrado que la idea de creatividad, genialidad y locura ha tornado según una civilización, una cultura y una sociedad dada. O que todas han creado sus seres a los que admirar, sus mitos, y que éstos han respondido a una serie de necesidades. También el campo de la psicología, cuyos estudios, en su mayoría, han buscado aislar las singularidades psicológicas de los individuos creadores -tratando de dar validez científica al mito-, han dado muestra de grandes lagunas en el conocimiento de estas cuestiones, apoyándose más en el mito:

“Estos análisis suscitan la posibilidad de que la búsqueda del genio esté mal encaminada, y que la noción de genialidad, definida como un conjunto de características psicológicas de un individuo creador, sea tan sólo un mito" (Weisberg, 1988: 93)

Se puede decir que estos atributos no se corresponden con la realidad. Sócrates, Nietzsche, Einstein, Goethe y otros que aparecen en los diálogos y en los textos, pudieron destacar de forma excepcional en algunas facetas o en algunos momentos de su vida. Pero también, inevitablemente, pasaron por fases de absoluta escasez e improductividad, de planteamientos y teorías ineficaces, inertes, o sin ninguna validez o sentido. Einstein le dice a Needleman en el texto Einstein le escribió en cierta ocasión: "Su obra y la mía son muy similares, aunque no tengo una idea muy exacta sobre qué versa la suya” (Allen y Sunshine, 1993: 64).

Otros grandes personajes también tuvieron una porción de errores importantes, como es el caso de Leonardo da Vinci:

“...ideó un muevo método para pintar sobre yeso, que le permitió pintar sus frescos de La última cena con un poco más de calma; pero desdichadamente, su método provocó que los colores perdieran su intensidad prematuramente, por lo que La última cena se encuentra hoy, relativamente, en mal estado" (Weisberg, 1988: 111).

Un ejemplo más de las cuestiones que estamos indagando de la obra de Allen, se encuentra en el diálogo del capítulo que hemos titulado Mi admirado genio me ha fallado. Lester (Woody Allen), no entiende por qué su admirado genio que ha dedicado su vida a predicar amor y esperanza, se ha suicidado. 
Cuadro 6: Mi admirado genio me ha fallado (Delitos y faltas, 1989)

Interior. Almacén películas. Día

Lester: [...] Ese hombre no estaba enfermo. Ha dejado una nota, ha dejado una simple nota diciendo: "he salido por la ventana". Era un intelectual importante, y sin embargo, fijate en su nota "he salido por la ventana" Qué coño significa eso. Ese hombre era un personaje modelo, debió dejar una nota decente [...]

Wendy: Precisamente, pensaba que, en fin, por muy elaborada esté la filosofía de uno, al final, siempre resulta incompleta.

Fuente: Allen, W. (2007): Delitos y faltas, Barcelona: Tusquets

Quizá Weisberg esté en lo cierto:

“El examen de los cuadernos de Leonardo revela otros ejemplos de esta suerte, lo cual demuestra, sencillamente, que hasta los más grandes científicos e inventores siguen siendo seres humanos y, como tales, falibles. Así pues, la creencia de que el genio es una característica constante queda de nuevo en entredicho” (Weisberg, 1988: 111).

La idea de que "los genios no siempre han sido geniales", desmonta el mito que diviniza a estos personajes y el hecho de que posean unas características psicológicas realmente diferenciadoras. En ese sentido, también es especialmente conocida la crítica de Allen hacia los intelectuales, a los estamentos que los sustentan: "Los intelectuales solo matan a los suyos", versa una mítica frase suya. La muy conocida secuencia de Annie Hall, puramente cinematográfica, que nosotros hemos titulado Qué sabe usted de Marshall MacLuhan (Allen, 1977), es una brillante reflexión sobre esta cuestión, en un homenaje al juego cinematográfico. Pero también, nos dice Allen, se debe a que hayamos confiado en exceso en la lógica y en el cerebro.

Cuadro 7: Usted no sabe nada sobre Marshall MacLuhan (Annie Hall, 1977)

Interior. Vestíbulo de un cine. Día.

Una larga cola de gente esperando. Murmullos de conversaciones. Alvy y Annie se hallan en mitad del grupo. A su lado, un hombre perora animadamente.

Hombre en la cola: El martes vimos la película de Fellini. No es una de las mejores. Le falta una estructura coherente. Ya sabes, da la impresión de no estar absolutamente seguro de lo que quiere decir. Claro que esencialmente me pareció siempre que no era más que un director que domina la técnica. «La Strada» era una gran película, desde luego. Grande en utilización de imágenes negativas más que nada. Pero la simple coherencia...

Alvy: Me, me, me va a dar un ataque.

Annie: Pues no le escuches.

Hombre en la cola (al mismo tiempo): En fin, tendría que ligar una idea con la otra. ¿Entiendes lo que te quiero decir?

Alvy (suspira): Si me grita sus opiniones al oído. 
Hombre en la cola (al mismo tiempo): Es como «Giulietta de los espíritus»o «Satyricon», me parecieron las dos de una complacencia increíble. Es el problema de Fellini, vaya. Es uno de los directores que más se complace. No te quepa la menor duda. Alvy (al mismo tiempo): La palabra clave es complacencia.

Hombre en la cola (al mismo tiempo): Sin conseguirlo, bueno, pues dejémoslo así.

Alvy (al mismo tiempo): ¿Por qué estás de mal humor?

Annie: No fui a la analista. Me quedé dormida.

Alvy: ¿Cómo es posible que te quedaras dormida?

Annie: El despertador.

Alvy: ¿Te das cuenta de la agresividad hacia mí que representa ese gesto?

Annie: Ya sé, te refieres a nuestro problema sexual, ¿verdad?

Alvy: Oye, tú... ¿es que la cola entera del New Yorker tiene que enterarse de la frecuencia de nuestras relaciones sexuales?

Hombre en la cola: Es como Samuel Beckett, ya sabes, admiro la técnica, pero, pero no lo siento en las tripas.

Alvy: Ya me gustaría que sintieras en las tripas un buen puñetazo.

Hombre en la cola (al mismo tiempo): Si no se consigue eso...

Annie: ¡Basta ya, Alvy!

Alvy (retorciéndose las manos): ¡Oye, que me escupe en el cuello! Me está escupiendo en el cuello al hablar, ¿sabes?

Hombre en la cola (al mismo tiempo): Y luego, lo más importante de todo, es que se trata de la visión de un cómico.

Annie (al mismo tiempo): ¿Y sabes tú otra cosa? ¡Eres tan egocéntrico que, si a mí se me olvida ir a la analista, sólo te preocupa lo que eso pueda afectarte a ti!

Hombre en la cola (al mismo tiempo): Miedo a las mujeres, eso es lo que es.

Alvy (al mismo tiempo) ¿Qué te juegas a que es su primera cita?

Hombre en la cola (al mismo tiempo): Una visión muy corta de miras. (Se pone un cigarrillo en la boca.)

Alvy: ¿A que se han conocido por un anuncio en la «New York Review of Books»? «Académico en la treintena desea conocer a mujer interesada en Mozart, James Joyce y la sodomía.» (Suspira) ¿Qué quiere decir eso de «nuestro problema sexual»?

Annie: ¡Oh!

Alvy (al mismo tiempo): Yo, yo, bueno, soy relativamente normal para estar criado en Brooklyn.

Annie: Vale, te presento mis disculpas. ¡Mi problema sexual! ¡Muy bien, mi problema sexual! ¿Eh?

El hombre frente a Annie y Alvy se vuelve para mirarles.

Alvy: Eso no lo he leído nunca. ¿No será, no será, de la novela de, de Henry James, eso es, el que escribió la continuación de «La vuelta de tuerca»?

Hombre en la cola (al mismo tiempo): Es la influencia de la televisión. Sí, ahora Marshall McLuhan es, dentro de los límites de su esencia, una, una gran, ah, una gran fuerza, ¿entiendes? Un medio caliente... en cuanto se opone a un... 
Alvy (al mismo tiempo): ¿Qué no haría yo por cubrirle de mierda hasta las cejas!

Alvy gesticula con frustración. El hombre en la cola se le encara.

Alvy (suspira, habla a la cámara): ¿Qué se puede hacer cuando te encuentras atrapado en la cola con un tipo como ése detrás tuyo? Vamos, es enloquecedor.

Hombre en la cola: Un momento, ¿por qué no puedo expresar mi opinión? ¡Este es un país libre!

Alvy: Naturalmente que la puede expresar... ¿Por qué tiene que expresarla a voz en grito? Quiero decir, ¿no le da vergüenza pontificar de esa forma? Ah, y eso es lo mejor, Marshall McLuhan. ¡Usted no sabe una palabra de Marshall McLuhan... ni de su obra!

Hombre en la cola (al mismo tiempo): ¡Un momento! ¿De veras? ¿De veras? ¡Pues da la casualidad de que en la universidad de Columbia tengo un curso sobre «Medios televisivos y Cultura»! Por eso creo que mis intuiciones sobre el señor McLuhan, bueno, son perfectamente válidas.

Alvy: ¿Conque sí, eh?

Hombre en la cola: ¡Sí!

Alvy (al mismo tiempo): Pues tiene gracia, porque resulta que el señor McLuhan está aquí en este preciso momento.

Alvy se dirige a un poster, tras el cual se halla Marshall McLuhan, y le hace aproximarse.

Alvy: Aquí, aquí, permítame... Muy bien. Venga aquí... un momento.

Hombre en la cola: ¡Oh!

Alvy (a McLuhan): Dígaselo usted.

McLuhan: He oído... he oído lo que estaba usted diciendo. Usted, usted no sabe nada acerca de mi obra. Hasta mis falacias las explica al revés. Que haya llegado usted a dictar un curso es algo que excede los límites de mi comprensión.

Alvy (a la cámara): ¡Cielos, si la vida pudiera ser siempre así!

Fuente: Allen, W. (1999): Annie Hall, Barcelona: Tusquets.

Cuadro 8: El cerebro... el órgano más sobrevalorado (Manhattan, 1979)

\section{Interior. Museo. Día}

Mary: Mira, allí está Saturno. Saturno es el sexto planeta del sistema solar. ¿Cuántos satélites de Saturno puedes nombrar? Está Mimas, Titán, Dione, Hiperión, claro está.

Isaac: No puedo nombrar ninguno. Por suerte, nunca surgen en mis conversaciones.

Mary: Hechos. Sí, tengo millones de hechos en la punta de la lengua.

Isaac: Así es, y no significan nada, ¿verdad? Porque nada que valga la pena saberse puede ser entendido con la mente. Todo lo que en verdad es valioso debe entrar por una abertura diferente... si me perdonas el uso del asqueroso lenguaje figurado.

Mary: Yo no estoy de acuerdo. ¿Dónde estaríamos sin el pensamiento racional?

Isaac: Confías demasiado en tu cerebro. Yo creo que el cerebro es el órgano más sobrestimado.

Fuente: Allen, W. (1999): Manhattan, Barcelona: Tusquets 
La creatividad es un instrumento más con el que se ha dotado al ser humano, que le es necesaria para su subsistencia, y que es tan múltiple y variada, como seres humanos y circunstancias existen. Véase en este sentido el texto titulado Mi hermano Theo. Aquí Woody Allen se pregunta ¿qué hubiera sucedido si los impresionistas hubieran sido dentistas? La respuesta se escapa de toda lógica.

Los teóricos de la creatividad, como Weisberg, apuntan a direcciones similares:

“El filósofo griego Heráclito creía que el único aspecto en el que el mundo se mostraba constante era la constancia del cambio. Resumió esta idea en su conocido dicho de que nadie puede bañarse dos veces en el mismo río. Lo cual es cierto, pues el río está cambiando constantemente. [...] Si los humanos nunca producen dos veces la misma respuesta, lo normal será, entonces, la novedad y, por tanto, la creatividad" (Weisberg, 1988: 192).

Todo este planteamiento nos lleva al ejemplo de Los "estúpidos" y los "genios" en la película Manhattan (Allen, W. 1979), cuando Ike (Woody Allen) le dice a Mary (Diane Keaton): "Oye, conoces a muchos genios, sabes... Deberías tratar algún estúpido de vez en cuando, podrías aprender algo". La desmitificación vuelve a aparecer como una constante en su obra.

En línea a estos planteamientos, entendemos que el hecho de que Allen desmitifique, haga esta crítica a los intelectuales y se acerque con sarcasmo e ironía a los que han sido considerados grandes genios, esté motivado por la sociedad en la que le ha tocado vivir. Y esto nos lleva directamente a poner la atención, una vez más, a la variable sociocultural, dando un paso más allá en el entendimiento de las razones por las que Woody Allen hace esta interpretación de los mitos.

Para las sociedades occidentales y, más concretamente, la norteamericana, el éxito, el "llegar a ser" y el reconocimiento social, son pilar fundamental de su cultura. Por eso él muestra especial atención e interés a los que están "fuera". Si la imaginación y la creatividad tiene sentido, en este caso, es fuera de aquella. En muchas de sus películas y escritos aparecen personajes fracasados, como en Broadway Danny Rose (Allen, 1984), o fuera de la ley, como en Toma el dinero y corre (Allen, 1969) o en Balas sobre Broadway (Allen, 1994).

La película Balas sobre Broadway (fragmentos a los que hemos titulado El "genio" y el "matón") resulta ser una síntesis de todas las proposiciones tratadas sobre la creatividad, la creación artística, los genios y sus mitos en la obra de Allen, una síntesis de la visión de estas cuestiones en el pensamiento occidental, en nuestras variables socioculturales. A Chip, el matón, lo representa con especial ternura. Aquí, vuelven a aparecer los temas que ya hemos visto en otras películas. La crítica a las instituciones de enseñanza, dice Chip: "aprendí a escribir antes de pegar fuego a mi escuela” (Allen, 1994, Balas sobre Broadway) o "no hagas caso a los profesores, yo odio los profesores". David, no entiende por qué no le surgen a él esas ideas, pues lleva media vida estudiando dramaturgia. Y a partir de aquí vuelven a salir los temas ya conocidos respecto a la creatividad y sus mitos: la casualidad del talento, lo innato en relación al talento, el papel de la educación, del entorno y la familia, etc.: 
Cuadro 9: El "genio" y el "matón" (Balas sobre Broadway, 1994)

Interior. Billares. Día.

David (suspira): Me gusta este sitio.

Cheech: Hace tiempo que vengo.

David: ¿Sí?

Cheech: Sí.

David: ¿Eres de por aquí? ¿Vives... vives... cerca de aquí?

Cheech: Nueva York. He nacido y crecido aquí. En la calle 45 Oeste.

David: Humm. ¿Tienes mucha familia?

Cheech: No. Una hermana que vive en Jersey...Tenía un hermano pero lo mataron.

David: Lo siento.

Cheech: No pasa nada. Intentó pasarse de listo con unos prestamistas. Lo llevaron a Canarsie y le volaron la tapa de los sesos.

David: ¿A tu hermano? ¿Cómo empezaste a dedicarte a esto?.

Cheech: ¿A esto?

David: Sí.

Cheech: Mi padre. Era una bestia (rie).

David: ¿Has pensado en dedicarte a otra cosa?

Cheech: ¿Cómo qué?

David: Como escribir.

Cheech: ¿Escribir?

David: Sí.

Cheech (risas): Venga ya. Estoy en la mafia desde los dieciséis años.

David: Pues tienes un gran talento.

Cheech: Sí, claro.

David: No, no, lo digo en serio. De verdad, es... es increíble. Me refiero a tu instinto.

Cheech: Deja que te diga algo.

David: Instinto dramático.

Cheech: Escúchame. Tu obra era muy buena.

David: Es... es... de verdad que es envidiable.

Cheech: Tu obra era muy buena. Pero no usaste la cabeza. A veces la gente no piensa.

David: Sí, claro. Para ti es muy sencillo. Al que sabe dibujar todo le parece lógico. Pero para quien no sabe... Yo he estudiado dramaturgia con muchos profesores, y me he leído un montón de libros.

Cheech: ¿Sabes una cosa? Yo odio a los profesores. Todavía me acuerdo de todas aquellas zorras de pelo azul que nos pegaban con la regla. Olvídate de los profesores.

David: Cuando era pequeño conocí a un chico que tocaba el acordeón.

Cheech: ¿Y?

David: A mí me encantaba el acordeón. Practicaba a todas horas y llegué a tocarlo con soltura. Él, sin embargo, con una sola nota te hacía llorar.

Cheech: A mí, en cambio, me hubiera gustado bailar.

David: Llorar... 
Cheech: Quería bailar. ¿Has visto alguna vez bailar a George Raft?

David: Sí, claro.

Cheech: Ah.

David: Esto...

Cheech: ¿Qué?

David: El señor Marx dice que... esto... que te has cargado a unos cuantos ¿Es cierto?

Cheech: ¿Qué es esto? ¿Un interrogatorio?

David: No, qué va.

Cheech: ¿Y entonces por qué lo haces?

David: Es solo que... la verdad estoy fascinado.

Cheech: Me he cargado a unos cuantos tipos.

David: ¿Por qué?

Cheech: ¿Por qué? ¿Por qué? No sé por qué. Porque se la jugaron al señor Valenti. Por no pagar sus deudas. Te diré una cosa: nunca me he cargado a nadie que no se lo mereciera.

David: Eh... y qué se siente cuando... pues eso, cuando...

Cheech: ¿Cuándo qué?

David: Al matar a un hombre.

Cheech: Te sientes bien.

David: ¿Te sientes bien?

Cheech: Sí.

David: ¿Incluso la primera vez?

Cheech: ¿La primera vez? La primera vez fue un maleante en la cárcel. Me delató y yo le clavé un pica-hielo en la espalda.

David: ¿Un pica-hielo?

Cheech: Sí, un pica-hielo. Tuve que clavárselo y volvérselo a clavar. Cuarenta veces.

David: ¿En la espalda?

Cheech: Quedó hecho un desastre. Olvídalo

Fuente: Allen, W. (1998): Balas sobre Broadway, Barcelona: Tusquets

Especial interés tiene la conversación entre el joven dramaturgo David, y sus compañeros artistas. En este diálogo se recogen toda suerte de mitos en torno al arte. Estos mitos son propios del romanticismo y la modernidad. La concepción del artista bohemio, marginado, incomprendido. Se puede decir que se sienten artistas en cuanto a mito, pero esto también les da algo de verdad.

Cuadro 9.1.: El "genio" y el "matón" (Balas sobre Broadway, 1994).

Exterior. Terraza. Noche

David (Off): Os digo que han leído mi obra...Les ha encantado. Pero están asustados.

Flender (Off): Eso es irrelevante. Irrelevante.

David: No es irrelevante.

Flender: Lo que sostengo es...es que no hay un solo artista auténtico que haya obtenido reconocimiento en su época. 
Lili (Off): No lo entiendo.

David: ¿No? ¿Ninguno?

Flender: ¡No! No, no, no.

David: ¡Flender!

Rita: Cierto. Eso es cierto. Muy cierto.

Flender: Piensa, piensa, esto... en Van Gogh, o...o en Edgar Allan Poe.

Rita: Exacto.

Flender: Poe, eh, murió pobre y aterido con su, con su gato arrebujado a sus pies.

David (Off): Oh.

Rita: Eso mismo, David. No te rindas nunca. Quizás te las den en post mortem.

Flender: ¿Sabéis...? Yo... yo... yo nunca he estrenado una obra, y he escrito una al año durante los últimos veinte años.

$[\ldots]$

David: Sí, pero es porque eres un genio. Y la prueba es que todo el mundo, tanto la gente corriente como los intelectuales, opina que su trabajo es incomprensible. Eso significa que eres un genio.

$[\ldots]$

Rifkin (Off): Todos tenemos nuestros momentos de duda. Yo pinto un cuadro cada semana, le doy un vistazo y acto seguido lo rasgo con una hoja de afeitar.

Lili: Porque no tienes fe en tu obra.

Rita: Te ves impelido a hacerlo.

Flender: Bueno, en tu caso es una buena idea.

Ellen: Yo creo en tus obras, David. Siempre he creído en ellas.

David: Sí, claro, cree en mis obras porque me quieres. Pero...

Ellen: No. Y también porque eres un genio.

[...]

Rita (Off): Oye, Ellen, no le dejes. Al fin y al cabo es un buen hombre. Las mujeres cometemos el error de enamorarnos del artista. Eh, chicos, ¿me escucháis?

David: Sí. Sí, te escucho.

Rita: Nos enamoramos del artista, no del hombre.

Flender: Yo no creo que eso sea un error. ¿Por qué iba a ser un error?

Lili $(O f f)$ : Son inseparables. Son inseparables...

Rita: Es lo mismo. El artista hace al hombre.

Flender: Creo que ella tiene razón, son inseparables. No, no.

Rita: Lo siento.

Flender: Esto, esto, supongamos, supongamos que se quema un edificio...

David (Off): Sí.

Rita: Sí.

Flender:... Y, y tu entras corriendo y solo puedes salvar una cosa...

Rita: Sí.

Flender: ... elegir entre, entre el último ejemplar de las obras completas de Shakespeare y un ser humano anónimo. 
David (Off): No se puede.

Rita: Pero eso...

Flender: ¿Qué harías? ¿Qué harías?

David (Off): No se puede privar al mundo de esas obras.

Flender: Exacto.

[...]

Ellen (Off): Es un objeto inanimado.

Flender: No es un objeto inanimado. Es arte. El arte es vida... tiene vida.

Fuente: Allen, W. (1998): Balas sobre Broadway, Barcelona: Tusquets

Estos personajes, como todos los que aparecen en esta película, son genuinos, auténticos. iQuién no puede querer a Oli, la espantosa actriz? Es un personaje lleno de belleza y de verdad. Todos los personajes se reinventan y se crean así mismos. Igual que el gánster que, irremediablemente hace que nos sintamos cerca de él, de ese personaje que, como él afirma, conoce el lenguaje de la calle. Cuando David le señala que él utiliza la licencia poética, Chip le responde: "Chorradas. La gente cree en lo que ve cuando los actores parecen de verdad... Yo sé cómo habla la gente” (Allen, W. 1994, Balas sobre Broadway).

Y ahí es donde Allen coloca la creatividad, la genialidad, y también la locura. Fuera de la legalidad establecida, de las aulas, en la calle, dónde cobra verdadero sentido y se hace necesaria. Dónde Chip tuvo que aprender. A Chip lo podríamos entender como simbolización de todas esas ideas sobre las que hemos estado reflexionando. ¿Qué sería de Chip sin la pura y viva imaginación de la supervivencia? Y por otro lado, ¿Qué hubiera sido de David, si no hubiera utilizado su imaginación para resolver todos sus problemas para llevar su obra a escena?

Todos los procesos creativos, en su origen primario, son mecanismos de supervivencia y, por ello, guardan gran similitud. La complejidad del problema a tratar es lo único que establece la diferencia. Dice Weisberg (1988: 190):

“[...] una de las presunciones básicas del punto de vista que actualmente estamos defendiendo es que en todos los tipos de situaciones intervienen los mismos procesos intelectuales, y que no debe hacerse distinción entre los procesos de pensamiento que intervienen en la actividad creadora y los que intervienen en cualquier otra actividad."

Por ello, si la invención y la creatividad es el instrumento para la resolución a un problema dado, no lo podemos entender sino como un elemento inherente al ser humano.

\section{El psicoanálisis y la locura}

De nuevo volvemos a Grecia. Desde Platón -con la expresión de "locura divina" para definir la inspiración y, por tanto, la creación-, hasta nuestros días, se ha mantenido el mito del genio y su relación con la locura. 
Woody Allen vuelve a relativizar sobre este hecho, su perspectiva o punto de vista se encuentra dentro de un marco cultural. Él, como creador, también "padece" el mito del genio loco y neurótico. Y quizá haya algo de cierto. Pero repasando su filmografía, nos damos cuenta de que no es algo que pertenezca a un solo personaje, todos en mayor o menor medida, padecen algún tipo de trastorno, de neurosis y acuden al psicoanalista. Lo representa, más bien, como un rasgo específico de la sociedad neoyorquina, más que como un rasgo diferenciador de ciertas personalidades. Como resultado de nuestras sociedades contemporáneas.

Cuadro 10: Tu autoestima está casi por debajo de la de Kafka (Manhattan, 1979)

Interior. Apartamento. Día

Mary: No sabía a quién llamar, y...

Isaac: no deberías tomar Valium, porque creo que produce cáncer.

Mary: no...medio Valium?

Isaac: sí, sí, cáncer abdominal, creo...

Mary: ¿Cuándo lo han descubierto?

Isaac: Aah, es, es una teoría mía, pero creo que es correcta. (Se va hacia el fondo de la habitación y susurra en voz baja) Tengo toallas de papel por alguna parte.

Mary: Creo que me merezco todo lo que me pasa.

Isaac: Oh, vamos...

Mary: es cierto, muy cierto. Yo sabía perfectamente que no podía resultar.

Isaac: Ya, te lías con un tipo casado, luego no resulta y ello confirma tus peores presentimientos.

Mary: ¿Qué peores presentimientos?

Isaac: pues tus ideas sobre el hombre, el matrimonio...y que nada resulta, todas esas tonterías.

Mary: Ay, por favor, no me psicoanalices...para eso pago a un médico.

Isaac: Oye ¿a ese tipo que te telefonea le llamas médico? ¿no, no te entran sospechas cuando tu psicoanalista te llama a las tres de la madrugada y te lloriquea por teléfono?

Mary: ya sé que es poco ortodoxo, pero es un médico muy competente.

Isaac: pues ha hecho una gran labor contigo, tu autoestima está casi por debajo de la de Kafka.

Fuente: Allen, W. (1999): Manhattan, Barcelona: Tusquets

Por tanto, partiendo de este caso concreto, podemos establecer una generalización, y entender el tema del "genio loco", como una cuestión social y cultural. En este sentido, son interesantes ciertos pasajes del libro de George Rosen Locura y sociedad. Sociología histórica de la enfermedad mental. La idea de que cada sociedad ha conformado ciertos comportamientos como patológicos y ha padecido sus propias epidemias psíquicas encaja perfectamente en los límites de la desmitificación que propone Allen, en los límites de nuestras hipótesis, en los procesos de autoconciencia a los que nos lleva el Arte y la creación artística. 
Al respecto, nos parece relevante destacar el siguiente fragmento del libro de Rosen: "Según Rennie y Woodward, 'la salud mental no se puede desarrollar en un vacío social. Tal como está constituida nuestra sociedad actual, actúan contra esa salud numerosos factores... La salud mental sólo se puede conseguir en un ambiente que proporcione oportunidades para la autoexpresión, para la utilidad social y para la obtención de satisfacciones humanas'. Esta actitud no dista mucho del punto de vista de que las neurosis individuales son efectivamente exponentes de una sociedad enferma, de que en realidad el paciente es la sociedad" (Rosen, 1968: 204).

Cuadro 11: Sólo llevo 15 años en el psicoanalista (Annie Hall, 1977)

Exterior. Calle. Día

Conversación Annie y Alvy

$[\ldots]$

Alvy: Ya nos veremos.

Annie (gesticula, al mismo tiempo): Oye, bueno, mira, ¿quieres subir a tomar una copa de vino y picar algo? Ah, no, quiero decir... quiero decir, no estás obligado, igual tienes prisa y todo eso...

Alvy (al mismo tiempo): No, no, me parece muy bien. No me importa. De veras.

Annie: ¿Seguro?

Alvy (al mismo tiempo): Sí, tengo tiempo.

Annie: Entonces, vale.

Alvy: De veras, no tengo... no tengo nada que hacer hasta la sesión con mi analista.

Annie: Oh, ¿vas al analista?

Alvy: S-s-sí, desde hace quince años.

Annie: ¿Quince años?

Alvy: Sí, le voy a conceder un año más y luego iré a Lourdes.

Annie: Quince... caramba, ¿estás...? Ya, ¿en serio?

Fuente: Allen, W. (1999): Annie Hall, Barcelona: Tusquets

El psicoanálisis ha tenido especial incidencia en la sociedad norteamericana. El hecho de convertir en patológicos todo tipo de comportamientos puede dar como resultado esas situaciones absurdas de los personajes que acuden al psicoanalista en las películas de Allen. En el film Annie Hall (Allen, W. 1977), Annie (Diane Keaton) vuelve del psicoanalista y le cuenta a Alvy (Woody Allen) su sesión. Su psicoanalista le ha dicho que padece "envidia de pene". A partir de aquí, relata todo tipo de acontecimientos de su vida que no sirven más que para justificar la propia teoría psicoanalítica. Pero este hecho se convierte en algo necesario, pues el psicoanalista tiene que justificar el cobro de sus consultas. Allen También muestra que la salud mental se ha convertido en un auténtico negocio en la sociedad norteamericana (véase el texto iEstos psicoanalistas modernos!).

Estos seres neuróticos de las películas de Woody Allen, también muestran una absoluta dependencia de todo tipo de medicamentos (Darvon, Valium...), de lo que una vez más hace parodia: 
Cuadro 12: Mi psiquiatra me sugirió que tomara Darvon (Sueños de un seductor, 1972)

Interior. Apartamento. Día

Linda: (dirigiéndose a Allan) ¿Tienes una aspirina? Me duele un poco la cabeza.

Dick: vaya, él en plena crisis, tú que te pones mala...

Linda: bueno, no te pongas tú nervioso.

Dick: no me pongo nervioso. Es que este está siendo un día muy duro para mí.

Allan (dirigiéndose a Dick): ¿Quieres una aspirina también?

Dick: no.

Allan: ooh... si me las he acabado todas ¿quieres Darvon Linda?

Linda: bueno...sí, mi psiquiatra ya me dijo que tomara Darvon cuando tuviera jaquecas

Allan: yo también tenía jaquecas pero me las curó mi psiquiatra, ahora cojo unos resfriados enormes.

Linda: yo sigo con las jaquecas pero es debido a la tensión.

Allan: según mi psiquiatra, para ponerme bien del todo necesito una lobotomía.

Linda: Yo, cuando el mío está de vacaciones me pongo a morir.

Dick: ¿por qué no os casáis y vivís en un hospital?

Allan: aahh... ¿quieres agua tónica con el Darvon?

Linda: ¿no tienes zumo de manzana?

Allan: zumo de manzana y Darvon...estupenda combinación.

Linda: ¿Has probado el Ixium con zumo de tomate?

Allan: yo no, pero otro neurótico amigo mío me ha dicho que es algo increíble.

Fuente: Allen, W. (2005): Sueños de un seductor, Barcelona: Tusquets

En este sentido, son oportunas las palabras de Brenot: "En la actualidad estamos acostumbrados a los medicamentos susceptibles de curar toda clase de enfermedades o de calmar el dolor...”(Brenot, 1998: 70). Sin olvidar los libros de autoayuda.

Cuadro 13: Era un presunto suicida (Annie Hall, 1977)

Interior. Teatro en universidad. Atardecer.

El público aplaude. Alvy gesticula en mitad del escenario con un micrófono en la mano. Un foco le ilumina.

Alvy: ¿D-dónde estoy? Yo, bueno... tengo que situarme. Esta es la Universidad de Wisconsin, ¿verdad? Es que yo... me pongo siempre... nervioso y... ah, cuando he de actuar en una uni... Mi historial universitario es desastroso. Sabéis, fui a la Universidad de Nueva York y... y, ah, me expulsaron el primer curso por copiar en el examen final de metafísica. Miré el alma de mi compañero de al lado...

Los estudiantes ríen a mandíbula batiente.

Alvy: ... y cuando me expulsaron, mi madre, que es una mujer hiperemotiva, se encerró en el cuarto de baño y se tomó una sobredosis de fichas de Mah-Jongg.

Los estudiantes ríen a mandíbula batiente.

Alvy: Y, vaya, eso me dejó muy deprimido. Entonces me... hice un psicoanálisis, yo, yo, eh, el caso es que yo tenía tendencias al suicidio, y me habría suicidado de no ser 
porque mi analista era un freudiano riguroso, y si te suicidas... te hacen pagar las sesiones pendientes.

Los estudiantes siguen riendo.

Fuente: Allen, W. (1999): Annie Hall, Barcelona: Tusquets

Ante este hecho de buscar causalidad a todo tipo de comportamientos susceptibles de desajustes psíquicos (como puede ser la relación entre genialidad y locura), así como el tema de la soledad, de la falta de referencias, de los millones de medicamentos milagrosos, Woody Allen no puede más que utilizar de nuevo el humor y un cierto sarcasmo, vuelve a desmitificar. Y trata de buscar una explicación, de encajarla en este caos, y de darle un sentido y utilidad. Y nos cuenta uno de sus más geniales chistes:

"Me acordé de aquel viejo chiste, ya saben, es la historia de aquel tipo que va al psiquiatra y le dice: "Doctor, mi hermano está loco, se cree una gallina” y el doctor le responde: “¿Por qué no le interna?”, y el hermano le replica: "lo haría, pero necesito los huevos". Pues bien, así es poco más o menos como suelo ver las relaciones entre la gente. ¿Saben?, completamente irracionales, locas y absurdas; pero creo que las mantenemos porque... La mayoría de nosotros necesitamos los huevos" (Allen, 1977. Annie Hall).

Los seres humanos necesitamos, pues, el Arte, la creación artística, el cine, los símbolos, para entender y entendernos.

\section{Conclusiones}

Las hipótesis que hemos planteado a lo largo de este trabajo están enfocadas a entender las variables y características de la creatividad como aspectos definitorios del ser humano. Dicho enfoque que se aleja pues, de un intento de buscar rasgos concretos que fueran susceptibles de dibujar un patrón más o menos fijo y/o estable que nos lleve de lo que se denominan personalidades creativas como tal. Es decir, una creatividad entendida desde la transdisciplinaridad, desde un enfoque que la sitúa como elemento constitutivo del ser humano pero con tantas coloraturas como personalidades se puedan dar, sin un patrón absolutamente fijo. Una creatividad entendida desde el proceso de autoconciencia en la consecución del desarrollo del ser humano. En ese sentido, el estudio de la obra y el trabajo de Woody Allen, el Arte y la creación artística han sido fundamentales para la consecución de nuestro objetivo.

Los mitos en torno a la creatividad y al genio, nos remiten, directamente al abordaje sociocultural de la creatividad. Y en ese proceso de desmitificación desde el que Allen acomete la cuestión que nos ha ocupado, las variables socioculturales, las variables externas, del entorno, tienen un papel determinante, pero siempre poniendo el acento en el desarrollo autodidacta de dichas capacidades por parte del individuo y, por tanto, dejando en una posición de mero condicionante a la educación, ubicándose así en la tradición romántica sobre dichas problemáticas. Dicha postura, que aún hoy sigue teniendo un peso central en nuestra contemporaneidad, llama a ser superada en la necesidad de un 
nuevo enfoque de la creatividad, un nuevo paradigma de la creatividad, que tocará las bases de la definición de Arte, las bases de nuestra episteme.

A modo de esquema podemos enumerar las siguientes conclusiones de nuestra investigación:

1. La creatividad es innata al ser humano, es constitutivo como capacidad de supervivencia y va más allá de unos rasgos concretos de personalidad.

2. Por ello, la creatividad debe abordarse desde un enfoque transdisciplinar, más allá de áreas concretas de conocimiento, es decir, no solo pertenece al mundo del arte.

3. Dentro de este marco teórico, Woody Allen desmitifica los mitos que han girado en torno a la creatividad y a la personalidad creadora.

4. Por tanto, se dan tantos rasgos de personalidad creadora como personalidades.

5. En este proceso de desmitificación, Woody Allen entiende el talento cuyo origen es pura suerte, la creatividad como una cuestión del destino.

6. En este marco teórico, entiende que la educación tiene un papel condicionante pero no determinante.

7. Entender que la creatividad es pura suerte y no educable, le sitúa en el contexto de la tradición romántica.

8. Las investigaciones actuales en neurociencia y psicología sobre la creatividad y sus procesos nos dicen que la creatividad es una suma de conocimientos y que el inconsciente puede ser adiestrado.

9. Asimismo, en relación al proceso creativo de Woody Allen podemos decir que Allen crea desde el ensimismamiento, es decir, desde la autoconciencia, máximo exponente de creatividad y que enlaza con esa idea contemporánea de inconsciente adiestrado.

10. Estos nuevos enfoques de la creatividad, sobre los procesos creativos y la personalidad creativa conforman un nuevo paradigma sobre la creatividad y la misma definición del arte.

\section{Referencias Bibliográficas}

Allen, W. (1999): Annie Hall. Barcelona: Tusquets.

- (1998): Cómo acabar de una vez por todas con la cultura. Barcelona: Tusquets.

- (1999): Manhattan. Barcelona: Tusquets.

- (2000): Hanna y sus hermanas. Barcelona: Tusquets.

$62\left|n^{\circ} 20\right|$ doxa.comunicación 
- (2007): Delitos y faltas. Barcelona: Tusquets.

Allen, W. y Sunshine, L. (1993): Woody Allen en imagines y palabras. Barcelona: Ediciones B.

Baelo Allu, S. (1999): “Parody an metafiction in Woody Allen's Mighty Aphrodite”, Epos: Revista de Filología, n. 15, pp. 391-408.

Bentley, G. (1978): William Blake’s Writings, vol. 2. Oxford University Press.

Bertorello, A. (2010): “Woody Allen, hermeneuta: cine y textualidad”, Escritura e imagen, n. 6, pp. 7-18.

Brenot, P. (1998): El genio y la locura. Barcelona: Ediciones B.

Cano, P. L. (1999): De Aristóteles a Woody Allen: poética y retórica para cine y tele. Barcelona: Gedisa.

Durán Manso, V. (2008): “Radio Days', de Woody Allen”, Frame, n. 3, pp. 235-245.

Gala, A. (1997): Poemas de amor. Barcelona: Planeta.

Granados Sancho, M. A. (2008): “Amor y muerte en Woody Allen”, Isagogé, n. 5.

Huerta Floriano, M. A. (2008): “El cine como terapia: el psicoanálisis en la obra de Woody Allen”, Revista de medicina y cine, vol. 4, n. 1, pp. 17-26.

Kemp, M. (2000): La ciencia del arte. La óptica en el arte occidental de Brunelleschi a Seurat. Madrid: Akal.

Kris, E. y Kurz, O. (1991): La leyenda del artista. Madrid: Cátedra.

Krystof, D. (1996): Modigliani. Colonia: Taschen.

Marina, J. A. (2013): El aprendizaje de la creatividad. Barcelona: Ariel.

Martín Puente, C. (2003): “Desmontando a Harry’ de Woody Allen y la literatura clásica: relaciones complejas entre la cultura clásica y la cultura contemporánea”, Estudios clásicos, tomo 45, no 123, pp. 27-42.

Oliván, L. (2002): “Woody Allen, en el diván”, Clarín: Revista de nueva literatura, año 7, n. 41, pp. 3-8.

Oria, B. (2007): “Genre and ideology in Woody Allen's AnotherWoman”, Revista alicantina de estudios ingleses, n. 20, pp. 167-183.

Ramírez, A. (2013): “Woody Allen de la A a la Z: [Woody Allen: El documental]”, Fotogramas, n. 2031, pp. 42-43.

Rosen, G. (1974): Locura y sociedad. Sociología histórica de la enfermedad mental. Madrid: Alianza.

Víquez Jiménez, A. (2010): “Woody Allen lee a Dostoievski”, Revista de filología y lingüística de la Universidad de Costa Rica, vol. 36, n. 1, pp. 157-172.

VV. AA. (2011): “La infidelidad en las películas de Woody Allen”, Aloma. Revista de psicología, ciències de l'educació i de l'esport, n. 29, pp. 309-324.

Weisberg, R. W. (1988): Creatividad: el genio y otros mitos. Barcelona: Labor. 


\section{Filmografía}

Allen, W., Sueños de un seductor, 1972.

Allen, W., Annie Hall, 1977.

Allen, W., Manhattan, 1979.

Allen, W., Hannah y sus hermanas, 1986.

Allen, W., Días de radio, 1987.

Allen, W., Delitos y faltas, 1989.

Allen, W., Balas sobre Broadway, 1994. 